\title{
OLAHRAGA DAN KESEHATAN REPRODUKSI
}

Oleh: I Nyoman Kanca

Dosen FPIK Universitas Negeri Pendidikan Ganesha Singaraja-Bali

Abstrak

Pelaksanaan program pelatihan olahraga yang bertujuan untuk meningkatkan kinerja gerak fisik seharusnya dapat menimbulkan respons adaptasi ketahanan tubuh yang tercermin dalam kondisi sehat. Kondisi sehat merupakan dasar dan sekaligus menjadi tujuan dalam pembinaan kebugaran jasmani

Pelatihan olahraga dapat meningkatkan ketahanan tubuh dan dapat digunakan untuk mengatasi kecepatan kemunduran organ dan pengembangan terapi biologik pada beberapa macam penyakit. Pelatihan olahraga yang teratur dapat meningkatkan kemampuan fisiologik organ tubuh $25 \%$ lebih tinggi dibandingkan dengan orang yang tidak aktif, demikian juga orang yang melakukan pelatihan olahraga yang teratur di waktu umur 50 tahun didapatkan kemampuan fungsi neuromuskulo-skeletal dan kardiorespirasi yang hampir sama dengan orang yang berumur 20-30 tahun. Pelatihan olahraga merupakan salah satu cara yang efektif untuk meningkatkan kondisi fisik, psikis, dan sosial seseorang, sebab dengan melakukan olahraga kebugaran seseorang tetap terjaga dan terhindar dari berbagai penyakit dan stres yang dapat mengganggu seseorang dalam melakukan aktivitas seksual. 
Kebugaran dan kesehatan fisik, psikis, dan sosial merupakan modal utama untuk dapat melakukan aktivitas seksual dengan optimal, dengan demikian kebugaran dan kesehatan fisik, psikis, dan sosial harus dijaga dengan baik melalui pelatihan olahraga. Seseorang tidak dapat melakukan aktivitas seksual apabila keadaan tubuh dan pikirannya terganggu. Jadi kehidupan seksual yang sehat terdapat pada pasangan yang sehat baik secara fisik, psikis, maupun sosialnya. Gairah seks bertambah berkat aktivitas olahraga yang teratur, sebab olahraga terbukti mampu meningkatkan kadar hormon testoteron bagi laki-laki dan hormon estrogen bagi perempuan. Kedua hormon tersebut memberi pengaruh langsung terhadap kemauan dan kepuasan seksual.

Kata kunci: olahraga, kesehatan, reproduksi.

Androgen adalah hormon seks steroid yang efeknya adalah maskulinisasi, estrogen adalah hormon yang menyebabkan feminisasi. Kedua jenis hormon secara normal disekresikan oleh kedua jenis kelamin. Testis mensekresikan sejumlah besar androgen, terutama testosteron, tetapi testis juga mensekresikan sedikit estrogen. Ovarium mensekresikan sejumlah besar estrogen dan sedikit androgen. Pada kedua jenis kelamin, androgen disekresikan oleh korteks adrenal dan sebagian androgen diubah menjadi estrogen di lemak dan jaringan lain. Ovarium juga mensekresikan progesteron, suatu steroid yang memiliki fungsi khusus dalam mempersiapkan rahim untuk hamil.

Perbedaan hormonal antara wanita dan pria memegang peranan yang sangat besar terhadap perbedaan penampilan seseorang. Testosteron yang disekresi oleh testis pria memiliki efek anabolik yang kuat terhadap penyimpanan protein yang sangat besar di setiap tempat di dalam tubuh, terutama di dalam otot. Pria yang sangat sedikit melakukan aktivitas olahraga memiliki testosteron yang banyak, akan memiliki otot yang akan tumbuh menjadi berukuran $40 \%$ atau lebih besar daripada otot pasangan wanitanya dan disertai peningkatan kekuatan yang sesuai.

MEDIKORA Vol. II, No. 2, Oktober 2006: 205 - 218. 
Hormon kelamin wanita estrogen mungkin juga berperan pada beberapa perbedaan penampilan antara wanita dan pria, walaupun tidak begitu banyak seperti testosteron. Estrogen diketahui meningkatkan penimbunan lemak pada wanita, terutama dalam beberapa jaringan khusus, seperti payudara dan paha. Timbal pertanyaan, apakah pelatihan olahraga berpengaruh terhadap kesehatan reproduksi?

\section{PELATIHAN OLAHRAGA}

Efek pelatihan olahraga dipengaruhi oleh: (1) intensitas, frekuensi, dan lamanya pelatihan, (2) genetik, dan (3) jenis kelamin dan umur. Secara umum, makin intensif, makin sering, dan makin panjang program pelatihan olahraga makin besar pengaruhnya pada kebugaran jasmani (Kanca, 2004). Untuk menjalankan program pelatihan olahraga bagi mereka yang tergolong atlet pemula dilakukan 3 hari per minggu, sedangkan bagi top atlet (atlet bertaraf nasional dan internasional) pelatihan dilakukan 6 hari per minggu (Kanca, 2004). Pelatihan olahraga merupakan bentuk pemberian beban pada tubuh yang mempunyai tujuan untuk kebugaran jasmani, rekreatif maupun prestasi dengan sasaran meningkatkan derajat kebugaran jasmani, kesehatan, dan prestasi.

Agar pelatihan olahraga tidak berdampak negatif terhadap fungsi organ tubuh, latihan olahraga sebaiknya dilakukan melalui 6 tahap, yaitu: (1) aktivitas peregangan (stretching) \pm 5 menit, (2) pemanasan (warming up) \pm 10 menit, (3) pelaksanaan latihan inti dasar (formal activity) \pm 45 menit, (4) latihan inti lanjutan \pm 45 menit, (5) aktivitas peregangan (stretching) \pm 5 menit, dan (6) latihan pendinginan (colingdown) \pm 10 menit (Kanca, 2004). Pembagian waktu pelatihan fisik tersebut di atas adalah sebagai contoh jika seseorang memprogram pelatihan olahraga selama 120 menit (2 jam).

\section{EFEK PELATIHAN OLAHRAGA PADA FAAL TUBUH}

Kondisi hidup sehat harus dibangun dan diimbangi dengan peningkatan kebugaran jasmani, sehingga memungkinkan seseorang memiliki tingkat daya tahan untuk mampu melakukan aktivitas sehari-hari tanpa merasa lelah dan menghasilkan kerja fisik atau nonfisik secara maksimal. Kondisi kebugaran jasmani yang baik akan menentukan status kesehatan sehingga tidak mudah sakit, energik, dan disiplin dalam beraktivitas. Tujuan berlatih olahraga adalah sebagai upaya 
untuk meningkatkan kebugaran jasmani, kesehatan, kualitas gerak fisik, dan pencegahan penyakit. Aspek kebugaran pada jenjang pembinaan olahraga dapat ditunjukkan dalam indikator total fitness yang meliputi kebugaran jasmani, kebugaran psikologis, dan kebugaran sosial.

Kualitas kebugaran jasmani dapat ditunjukkan dengan adanya peningkatan kemampuan seluruh sistem fisiobiologis tubuh. Kebugaran jasmani merupakan cermin kemampuan dan efisiensi respons fisiobiologis yang disertai dengan kondisi sehat (Bouchard, 1993). Jika ditinjau dari makna keterkaitan antara aktivitas fisik, kebugaran jasmani, dan sehat, aspek sehat dapat merupakan prasyarat dan tujuan dalam upaya pembinaan kebugaran melalui pelatihan olahraga. Pelaksanaan program pelatihan olahraga yang bertujuan untuk meningkatkan kinerja gerak fisik seharusnya dapat menimbulkan respons adaptasi ketahanan tubuh yang tercermin dalam kondisi sehat, sebab kondisi sehat merupakan dasar dan sekaligus menjadi tujuan dalam pembinaan kebugaran jasmani

Pelatihan olahraga yang teratur dapat meningkatkan kemampuan fisiologik organ tubuh $25 \%$ lebih tinggi dibandingkan dengan orang yang tidak aktif, demikian juga orang yang melakukan pelatihan olahraga yang teratur di waktu umur 50 tahun didapatkan kemampuan fungsi neuromuskuloskeletal dan kardiorespirasi yang hampir sama dengan orang yang berumur 20-30 tahun (McArdle, 1986). Latihan olahraga dapat meningkatkan ketahanan tubuh dan respons sistem saraf hormon terhadap sistem ketahanan tubuh menyebabkan peningkatan kualitas ketahanan tubuh (Setyawan, 1996). Latihan olahraga dapat digunakan untuk mengatasi kecepatan kemunduran organ dan pengembangan terapi biologik pada beberapa macam penyakit (Bouchard, 1993). Peningkatan kemampuan fisiologik pada sistem kardiorespirasi dapat ditunjukkan melalui efisiensi denyut jantung dan cardiac output. Adaptasi sistem metabolik dan saraf dapat tercermin pada kualitas neuromuskuloskeletal yang mendukung kekuatan, kecepatan, ketahanan kontraksi, kelincahan, dan koordinasi.

\section{ADAPTASI AKIBAT BEROLAHRAGA PADA SISTEM ENDOKRIN}

Sistem saraf dan sistem endokrin adalah merupakan dua sistem organ yang berperan besar terhadap respons dan adaptasi. Kedua sistem tersebut

MEDIKORA Vol. II, No. 2, Oktober 2006: $205-218$. 
bekerja untuk mengatur kecepatan aktivitas kimiawi sel di berbagai jaringan. Sistem saraf akan merespons lebih cepat terhadap perubahan homeostasis seluler dibandingkan dengan sistem endokrin. Walaupun sistem endokrin merespons lebih lambat, seringkali lebih besar dan lebih lama, sebab efek pengaturan endokrin pada fungsi sel sangat luas. Diperkirakan perubahan fungsi endokrin inilah yang bertanggung jawab terhadap berbagai respons dan adaptasi fisiologis terhadap pelatihan olahraga (Fox, 1988). Mekanisme aksi endokrin biasanya berbentuk tiga, yaitu: (1) perubahan kecepatan sintesis enzim protein, (2) perubahan kecepatan síntesis molekul, misalnya: cAMP atau prostaglandin yang kemudian mengubah aktivitas enzim atau permeabilitas membran sel terhadap substansi yang penting, (3) perubahan permeabilitas membran sel.

Perubahan konsentrasi hormon sangat sulit diinterpretasi karena konsentrasi hormon sewaktu-waktu dipengaruhi oleh berbagai variabel, seperti: (a) kecepatan kelenjar dalam memproduksi hormon, (b) kecepatan perusakan hormon oleh enzim di hati, ginjal, dan jaringan lain, (c) kecepatan ambilan hormon oleh jaringan, dan (d) perubahan volume darah. Dari fakta tersebut di atas dapat disimpulkan bahwa peningkatan konsentrasi hormon selama pelatihan olahraga dapat diinterpretasikan sebagai peningkatan produksi, pengurangan destruksi. 
Tabel 1. Perubahan Hormonal Selama Latihan (Exercise) dan Pelatihan (Training)

\begin{tabular}{|c|c|c|c|}
\hline Hormon & Respons & Berhubungan Khusus & Signifikan \\
\hline $\begin{array}{l}\text { Growth } \\
\text { Hormone }\end{array}$ & Meningkat & $\begin{array}{l}\text { Meningkat besar dengan latihan } \\
\text { intensif, norepinefrin, epinefrin, } \\
\text { meningkat } \\
\text { Peningkatan tidak sama pada } \\
\text { individu, cepat menurunkan } \\
\text { kebugaran seseorang }\end{array}$ & $\begin{array}{l}\text { Glukosa darah } \\
\text { meningkat, regulasi sistem } \\
\text { cardiovaskuler } \\
\text { Tidak pasti, mungkin } \\
\text { terlambat pemindahan } \\
\text { FFA }\end{array}$ \\
\hline $\begin{array}{l}\text { ACTH- } \\
\text { kortisol }\end{array}$ & Meningkat & $\begin{array}{l}\text { Meningkat besar dengan latihan } \\
\text { intensif, meningkat tidak sebanyak } \\
\text { sesudah pelatihan dengan latihan } \\
\text { sub maksimal }\end{array}$ & $\begin{array}{l}\text { Meningkatkan } \\
\text { glukoneogenesis dalam } \\
\text { hati (ginjal) }\end{array}$ \\
\hline LH-FSH & $\begin{array}{l}\text { Tidak ada } \\
\text { perubahan }\end{array}$ & $\begin{array}{l}\text { Menurun dengan pelatihan yang } \\
\text { keras atau berat }\end{array}$ & Amenorho \\
\hline Testosteron & Meningkat & - & $?$ \\
\hline $\begin{array}{l}\text { Estradiol- } \\
\text { Progesteron }\end{array}$ & Meningkat & Meningkat selama bersepeda & $?$ \\
\hline Insulin & Menurun & $\begin{array}{l}\text { Menurun tidak sebanyak sesudah } \\
\text { pelatihan }\end{array}$ & $\begin{array}{l}\text { Penurunan stimulus } \\
\text { memanfaatkan glukosa } \\
\text { darah }\end{array}$ \\
\hline Glukagon & Meningkat & $\begin{array}{l}\text { Meningkat tidak sebanyak sesudah } \\
\text { pelatihan }\end{array}$ & $\begin{array}{l}\text { Peningkatan glukosa darah } \\
\text { melalui glikogenolisis dan } \\
\text { glukoneogenesis }\end{array}$ \\
\hline $\begin{array}{l}\text { Prostaglandi } \\
\mathrm{n}\end{array}$ & Meningkat & $\begin{array}{l}\text { Respons meningkat secara terus } \\
\text { menerus pada kontraksi } \\
\text { isometerik }\end{array}$ & Terjadi vasodilatasi local \\
\hline
\end{tabular}

\section{ADAPTASI AKIBAT BEROLAHRAGA PADA HORMON PERTUMBUHAN}

Pelatihan olahraga menyebabkan perubahan fisiologis sistem hormonal di dalam tubuh. Peningkatan kadar suatu hormon di dalam darah akibat pelatihan olahraga dapat terjadi karena adanya kenaikan sekresi hormon tersebut oleh kelenjar endokrin (Lamb, 1984). Pelatihan olahraga diketahui merangsang pelepasan sejumlah hormon hipofisis, seperti hormon pertumbuhan, tyroid stimulating hormone (TSH), vasopresin, dan adenokortikotropik hormon (ACTH), sedangkan hormon gonadotropin, luteinizing hormon ( $\mathrm{LH})$, dan folliclestimulating bormone ( $\mathrm{FSH}$ ) mengalami penurunan (Lamb, 1984). Hormon pertumbuhan berasal dari kelenjar hipofisis anterior, di bawah pengaruh growth hormone releasing bormone (GHRH) yang dihasilkan oleh hipotalamus. Kelenjar hipofisis anterior

MEDIKORA Vol. II, No. 2, Oktober 2006: 205 - 218. 
biasanya dinamakan mastergland. Tiap hormon master gland mempunyai efek yang nyata pada fungsi tubuh pada saat istirahat dan selama kerja fisik (McArdle, 1986).

Growth hormone (GH) mempunyai aktivitas fisiologik yang luas, karena $\mathrm{GH}$ meningkatkan mitosis sel dan proliferasi seluler tubuh. Hormon pertumbuhan juga bermanfaat untuk otot, tulang, jaringan pertumbuhan, dan zat metabolik selama latihan fisik (McArdle, 1986). Peningkatan konsentrasi hormon pertumbuhan juga terbukti berhubungan dengan pelatihan olahraga (Lassarde, 1974). Pelatihan olahraga meningkatkan konsentrasi hormon pertumbuhan dalam darah, bahkan pelatihan dengan intensitas yang berat sangat meningkatkan konsentrasi hormon pertumbuhan (Guyton, 2000). Hormon pertumbuhan tidak segera meningkat selama pelatihan olahraga, tetapi berangsurangsur sesuai dengan waktu. Peningkatan pelepasan hormon pertumbuhan selama pelatihan olahraga berperan di dalam mobilisasi asam lemak bebas dan metabolisme (Shepherd, 1978).

Pelatihan fisik submaksimal meningkatkan hormon somatotropin dalam darah, (Lamb, 1984). Pelatihan olahraga meningkatkan konsentrasi hormon pertumbuhan pada orang yang sudah tua (Shepherd, 1978). Peningkatan hormon pertumbuhan dibutuhkan bagi orang yang sudah tua. Pada kerja fisik peningkatan hormon pertumbuhan manusia sedikitnya $30 \mathrm{mg} / \mathrm{ml}$. Kerja fisik yang berat dapat meningkat sampai lebih dari $120 \mathrm{mg} / \mathrm{ml}$ (Masson, 1972).

Pada umumnya, hormon membebaskan energi melalui mobilisasi glukosa hati dan asam lemak bebas dari jaringan adipose yang meningkat selama pelatihan olahraga. Termasuk di dalamnya adalah katekolamin, hormon pertumbuhan, dan glukagon. Sebaliknya, dengan insulin, hormon utama yang terlibat dalam penyimpanan energi menghambat pelepasan glukosa dari hati, dan asam lemak bebas dari jaringan adipose menurun selama pelatihan olahraga.

\section{OLAHRAGA DAN MENSTRUASI}

Menstruasi biasanya berlangsung 5-7 hari, oleh karena itu tidak dapat dihindarkan bahwa wanita harus berlatih atau berlomba dalam periode mentruasi. Menurut data-data yang terkumpul bahwa pemecahan rekor olahraga terjadi di semua fase dari siklus termasuk menstruasi. Oleh karena itu banyak pelatih yang tidak mengubah jadwal latihan maupun perlombaan. Jadi rupanya 
menstruasi tidak berpengaruh terhadap prestasi terutama dalam lari. Yang perlu diperhatikan adalah kekurangan besi pada mentruasi. Apabila kekuarangan persediaan besi, sebaiknya pada wanita tes hemoglobin $(\mathrm{Hb})$ dikerjakan apabila ada penurunan prestasi maupun ada gejala-gejala kurang darah.

Tabel 2. Penampilan Atlet pada Saat Mentruasi

\begin{tabular}{|c|c|c|c|c|c|c|}
\hline \multirow{2}{*}{ Peristiwa } & \multirow{2}{*}{ Pengikut } & Olahraga & \multicolumn{4}{|c|}{ Penampilan } \\
\cline { 4 - 7 } & & $\begin{array}{c}\text { Lebih baik } \\
(\%)\end{array}$ & $\begin{array}{c}\text { Tak berubah } \\
(\%)\end{array}$ & $\begin{array}{c}\text { Mundur } \\
(\%)\end{array}$ & $\begin{array}{c}\text { Tak Teratur } \\
(\%)\end{array}$ \\
\hline \multirow{3}{*}{ Olimpiade } & 72 & Atletik & 19 & 63 & 8 & - \\
\cline { 3 - 7 } & 62 & Aneka & 19 & 43 & 38 & - \\
\cline { 4 - 8 } & 122 & Aneka & 3 & 37 & 17 & 28 \\
\hline
\end{tabular}

\section{OLAHRAGA DAN KEBUGARAN REPRODUKSI}

Untuk mendapatkan kondisi fisik yang prima salah satunya dapat dilakukan dengan pelatihan olahraga secara kontinu dan teratur. Olahraga merupakan perilaku aktif yang dapat meningkatkan metabolisme dan mempengaruhi fungsi kelenjar di dalam tubuh untuk memproduksi sistem kekebalan tubuh dalam upaya mempertahankan tubuh dari gangguan penyakit dan stres. Satiadarma (2001) mengatakan bahwa olahraga merupakan aktivitas yang sangat penting untuk mempertahankan kebugaran. Berolahraga secara teratur membuat seseorang akan menjadi lebih bersemangat dan terlihat muda, tidak hanya itu olahraga juga dapat menghilangkan ketegangan, stress, dan ketakutan yang berlebihan yang mungkin dapat mengganggu kenikmatan dalam berhubungan intim. Olahraga juga membuat sirkulasi darah menjadi lebih lancar termasuk aliran darah yang menuju titik-titik peka yang mampu meningkatkan gairah seks. Hanya dari fisik yang sehat muncul seks yang sehat, dan fisik yang sehat sangat bergantung pada kesehatan fisik, mental, dan sosial (Boyke, 1996).

Kesehatan fisik dan psikis merupakan modal utama untuk dapat melakukan aktivitas seksual dengan optimal, dengan demikian kesehatan fisik dan psikis harus dijaga dengan baik melalui latihan olahraga. Boyke (1996)

MEDIKORA Vol. II, No. 2, Oktober 2006: 205 - 218. 
mengatakan bahwa seseorang tidak dapat melakukan aktivitas seksual apabila keadaan tubuh dan pikiran orang tersebut terganggu. Jadi kehidupan seksual yang sehat biasanya terdapat pada pasangan yang sehat pula baik secara fisik maupun psikis. Jika salah satu merasa tidak bugar, loyo, dan staminanya menurun bahkan merasa sakit, aktivitas seksual tidak akan optimal, demikian pula dengan keadaan psikhisnya, apabila ada masalah dan banyak pikiran aktivitas seksualnya tidak akan berjalan dengan baik.

Gairah seks bertambah berkat aktivitas olahraga yang teratur, sebab olahraga terbukti mampu meningkatkan kadar hormon testoteron bagi laki-laki dan hormon estrogen bagi perempuan. Kedua hormon tersebut memberi pengaruh langsung terhadap kemauan dan kepuasan seksual. Olahraga yang dilakukan sesuai dengan takaran yang benar akan dapat meningkatkan kebugaran jasmani seseorang (Sadoso, 2002). Dengan meningkatkan kebugaran jasmani, semua fungsi alat tubuh akan membaik, tidak terkecuali fungsi alat-alat kelamin baik pria maupun wanita. Dengan demikian kemauan dan aktivitas seksual akan meningkat serta frekuensi bermain akan menjadi lebih baik (Nala, 1992).

Selain menjaga kesehatan tubuh, latihan senam berperan menurunkan angka kesakitan dan kematian ibu serta bayi yang dilahirkan dan juga mampu meningkatkan kemampuan seks secara alami (Seputra, 2005). Dengan latihan fisik secatra rutin, teratur, dan berkesinambungan seseorang akan memperoleh kemampuan seksnya kembali setelah sebelumnya mengalami penurunan gairah seks (Sadoso, 2002). Para pakar kesehatan merekomendasikan bahwa untuk mengatasi masalah seksual dalam keluarga adalah dengan berolahraga secara teratur (Orakas, 1999). Kehidupan seksual yang sehat biasanya terdapat pada pasangan yang sehat baik secara fisik dan psikis (Ratnawati, 2001).

Salah satu bentuk olahraga yang dibutuhkan wanita berkeluarga untuk dapat mengatasi masalah seksualitasnya adalah berolahraga yang bertujuan menguatkan otot vagina yang dikenal dengan latihan otot vagina (Kuntaraf, 1992). Olahraga senam banyak digemari oleh wanita dewasa maupun wanita yang sudah berkeluarga. Hal ini dapat dilihat dengan makin banyak muncul klub sanggar senam yang diikuti oleh wanita berkeluarga. Banyak ragam senam yang dilatihkan di klub sanggar senam, hal ini bergantung pada tujuan dan jenis latihan senam yang dilatihkan. 
Dari berbagai pendapat tersebut di atas dapat disimpulkan bahwa pelatihan olahraga merupakan metode yang efektif dalam meningkatkan kondisi fisik, psikis, dan sosial seseorang sebab dengan melakukan olahraga kebugaran seseorang tetap terjaga dan terhindar dari berbagai penyakit dan stres yang dapat mengganggu seseorang dalam melakukan aktivitas seksual.

Salah satu jenis olahraga yang dibutuhkan untuk dapat melakukan aktivitas seksual adalah senam seks (kegel exercise). Tujuan semula dari latihan senam seks adalah untuk memperbaiki kelemahan otot vagina yang disebabkan oleh kerusakan-kerusakan akibat melahirkan dan mengatasi incontinentria urinae, tetapi latihan senam seks berkembang dan memberikan keuntungan-keuntungan, seperti: meningkatkan perasaan seksual pada otot-otot panggul (pelvis), meningkatkan respons seksual pada otot-otot panggul, dan meningkatkan kualitas dan kuantitas orgasme secara teratur.

Kuntaraf (1992) mengatakan bahwa latihan otot vagina akan memperbaiki tubuh seorang wanita untuk: (1) lebih siap dalam melahirkan, (2) mengontrol pengeluaran air seni, (3) mengurangi sakit belakang, (4) menambah kenikmatan bagi pasangan suami-istri.

Dengan melakukan senam seks secara rutin dan teratur sesuai petunjuk teknisnya, akan terjadi proses pembentukan, perbaikan jaringan otot pada vagina dan meningkatkan elastisitas jaringan otot vagina serta bermanfaat untuk membantu proses melahirkan seorang bayi (Listyarini, 1997). Latihan senam seks memperkuat bagian pinggul wanita sehingga kuat bersenggama dan menambah potensi seks wanita berkeluarga (Nugroho, 2001). Orakas (1999) mengatakan bahwa senam seks berguna untuk menyehatkan sehingga kebahagiaan dan kenikmatan rumah tangga bisa dinikmati dengan keadaan fisik dan psikis yang sehat.

\section{RESPONS BIOLOGIS MENOPAUSE TERHADAP OLAHRAGA}

Menopause adalah berhentinya menstruasi. Klimakterik (perimenopause) merupakan perubahan bertahap dari masa reproduktif ke masa nonreproduktif, suatu proses yang memakan waktu beberapa tahun untuk berhenti sama sekali. Menstruasi biasanya menjadi irreguler dan berhenti antara 45-55 tahun. Dengan kemajuan zaman, usia menopouse meningkat menjadi 52 tahun (Wells, 1985; Ganong, 2001).

MEDIKORA Vol. II, No. 2, Oktober 2006: 205 - 218. 
Kejadian utama pada wanita menopause yaitu produksi estrogen yang rendah bersama dengan peningkatan gonadotropin serum, FSH, dan LH. Menstruasi yang tidak teratur disebabkan oleh maturasi folikel ovarium yang tidak teratur pula, tanpa atau disertai ovulasi. Perdarahan vaginal masih terjadi setelah peningkatan dan penurunan estrogen. Masa transisi kemunduran fungsi menstruasi ini disebut perimenopouse.

Rasa panas memancar dari badan ke wajah (bot flashes), wanita menopause yang berolahraga, meskipun mengalami gejala tersebut, namun tidak seberat wanita yang tidak berolahraga. Apabila bot plash disebabkan oleh defisiensi estrogen, pengurangan gejala dapat disebabkan oleh kadar estrogen dan progesteron darah meningkat setelah berolahraga. Dimungkinkan, olahraga teratur dapat mengurangi derajat defisiensi estrogen perimenopausal, setidaknya mengaktifkan produksi estrogen yang bukan berasal dari ovarium. Apabila bot plash disebabkan oleh peningkatan LH yang pulsatil, latihan teratur akan mengurangi hot plash dengan menurunnya konsentrasi LH.

Sebuah hasil penelitian menemukan bahwa berolahraga dapat memperlambat onset menopause menjadi premenopause, dan postmenoupause menjadi mirip premenopause. Dua kelompok wanita pre dan postmenopause, $65 \%$ postmenopause sudah mengalami flushing ringan. Diberi perlakuan 6 minggu latihan, 4 kali per minggu, dengan intensitas latihan $70 \%$ denyut nadi maksimal. Volume oksigen maksimal $\left(\mathrm{VO}_{2}\right.$ maks) kedua kelompok meningkat bermakna dan lemak tubuh menurun. Estradiol (E2) meningkat pada kedua kelompok, dan profil estroneestradiol pada wanita postmenopausal mirip premenopausal. Beratnyaflushing menurun pada $36 \%$ wanita postmenopause dan $29 \%$ tidak berubah. Peneliti menyimpulkan bahwa pengkondisian fisik dapat memperlambat onsetmenopause melalui mekanisme yang meningkatkan konsentrasi estradiol serum (Guyton, 2000; Ganong, 2001).

\section{KEBUGARAN TUBUH MEMPERPANJANG KEHIDUPAN}

Berbagai penelitian menunjukkan bahwa orang yang mempertahankan kebugaran tubuh yang sesuai, menggunakan berbagai ragam latihan dengan bijaksana dan pengaturan berat badan, memiliki keuntungan tambahan, yaitu hidup lebih panjang. Khususnya antara usia 50 dan 70 tahun, penelitian telah 
menunjukkan bahwa kematian menjadi berkurang tiga kali lipat pada orang yang melakukan kebugaran daripada yang tidak melakukan kebugaran.

Guyton (2000) mengatakan bahwa kebugaran tubuh memperpanjang kehidupan. Hal ini disebabkan oleh: (1) kebugaran tubuh dan pengaturan berat badan sangat mengurangi penyakit kardiovaskular; Hal ini disebabkan oleh: (a) pengaturan tekanan darah yang cukup rendah, (b) pengurangan kolesterol darah dan lipoprotein densitas rendah bersamaan dengan peningkatan lipoprotein densitas tinggi, perubahan-perubahan ini semua bekerja bersama-sama untuk mengurangi jumlah serangan jantung dan stroke otak; (2) orang yang sehat secara atletik memiliki cadangan kebugaran jasmani yang lebih banyak apabila ia sedang sakit. Contoh, seorang yang berusia 80 tahun yang tidak melakukan kebugaran mungkin memiliki sistem pernapasan yang membatasi pemakaian oksigen tidak lebih dari 1 liter/menit, hal ini berarti bahwa cadangan pernapasan tidak lebih dari 3-4 kali lipat.

Usia harapan hidup manusia Indonesia pada tahun 1993 adalah 62 tahun, yang menjadi 65 tahun pada tahun 2000. Pada tahun 2000 jumlah penduduk berusia di atas 60 tahun berjumlah 7,2 \% dari seluruh populasi (Roeshadi, 1997). Peningkatan usia harapan hidup, perlu dibarengi dengan peningkatan kualitas hidup dan semestinya mendapat prioritas utama.

\section{KESIMPULAN}

Berlatih olahraga secara benar, kontinu, dan teratur merupakan metode yang efektif dalam meningkatkan kondisi fisik, psikis, dan sosial seseorang, sebab dengan demikian kebugaran seseorang tetap terjaga dan terhindar dari berbagai penyakit dan stres yang dapat mengganggu kebugaran jasmani pada umumnya dan kesehatan reproduksi pada khususnya.

Peningkatan usia harapan hidup, perlu dibarengi dengan peningkatan kualitas hidup dan semestinya mendapat prioritas utama. Pelatihan olahraga yang adekuat dan menyenangkan merupakan salah satu sarana untuk meningkatkan kualitas hidup, sebab berlatih olahraga yang benar, kontinu, dan teratur dapat membentuk kebugaran jasmani yang prima, menyehatkan termasuk menyehatkan reproduksi dan membentuk karakter seseorang untuk dapat hidup berkualitas dan mandiri dalam menghadapi, menjalani, serta mengisi kehidupannya.

MEDIKORA Vol. II, No. 2, Oktober 2006: 205 - 218. 


\section{DAFTAR PUSTAKA}

Bouchard, C., Shephard, R.J., \& Stephens, T. (1993). Physical Activity, Fitness and Health Consensus Statement. Kingwood, South Australia: Human Kinetics Publishers.

Boyke, D.N. (1996). “Cara Efektif untuk Menjaga Kesehatan dan Kebugaran.” Makalah. Jakarta.

Fox, E.L., Bowers, R.W., \& Foss, M.L. (1988). The Physiological Basis of Physical Education and Athletics. USA: Saunders College Publishing.

Ganong, W.F., (2001). Review of Medical Physiology, Twentieth Edition, USA: McGraw-Hill Companies, Inc. All rights reserved.

Guyton, A.C. (2000). Textbook of Medical Physiology. $8^{\text {th }}$ ed. West Washington Aquare: WB Saunders Company.

Kanca, N. (2004). "Pengaruh Pelatihan Fisik Aerobik dan Anaerobik terhadap Absorpsi Karbohidrat dan Protein di Usus Halus Rattus Norvegicus Strain Wistar." Disertasi. Program Pascasarjana Unair Surabaya.

Kartono dan Kartini. (1992). Psikologi Wanita. Bandung: Penerbit Mandar Maju.

Kuntaraf J dan Liwijaya K. (1992). Olabraga Sumber Kesehatan. Bandung: Percetakan Advent Indonesia.

Lamb, D.R. (1984). Physiology of Exercise Responses E Adaptations. New York: Macmillan Publishing Company.

Lassarde, C.et.al. (1974). "Kinetics Of Human Growth Hormone During Submaximal Exercise." J Appl. Physiol. 37:830-836.

Listyarini M. (1997). Panduan Olab Tubub Pria dan Wanita. Pekalongan: CV Gunung Mas.

Masson, A.S. (1972). Human Growth Hormone. $1^{\text {st. }}$.ed. London: William Heinemann Medical Books Limited.

Nala N. (1992). Kumpulan Tulisan Olabraga. Denpasar: Koni Propinsi Bali.

Nugroho A. (2001). Seksualitas dalam Perkawinan. Yogyakarta: Penerbit Maju Jaya.

Orakas S. (1999). Senam Seks. Pekalongan: CV Bahagia.

Pyke, F.S. \& Woodman, L.R. (1991). “Principles of Sports Training.” In Pyke, F.S. (eds). Better Coaching. Belconner, Australian coaching Council incorporated.

Rushadi D. (1997). "Deteksi Dini Osteoporosis pada Wanita Pra dan Pascamenopouse." Disertasi. Program Pascasarjana Unair Surabaya. 
Sadoso S. (2002). Meningkatkan Kemampuan Seks Secara Alamiah. Jakarta: Tokoh.

Satiadarma M. (2001). Menyikapi Perselingkuhan. Jakarta: Populer Obor.

Seputra A. (2005). "Senam Hamil Turunkan Angka Kesakitan Ibu." Makalab Seminar dan Workshop. Bali Post, Denpasar.

Setyawan S. (1996). "Pengaruh Latihan Fisik Aerobik dan Anaerobik terhadap Respons Ketahanan Tubuh." Disertasi. Program Pascasarjana, Universitas Airlangga Surabaya.

Shephard, R.J. (1978). Physical Activity and Aging. London: Croom Helm Limited.

Soekarman. (1989). Dasar Olahraga untukPembina, Pelatih, dan Atlet. Jakarta: CV Haji Masagung.

Wells, C.L. (1985). Woman, Sport E Performance: A Physiological Performance. Illinois: Human Kinetics Publisher, Inc.

MEDIKOBA Vol. II, No. 2, Oktober 2006: $205-218$. 